\title{
Repair of Truncus Arteriosus, Type 1 in Nigeria: A Case Report Nwafor IA ${ }^{1 *}$, Novick W², Adiele $\mathrm{DK}^{3}$, Eze $\mathrm{JC}^{1}$, Ezemba ${ }^{1}$, Chinawa $\mathrm{JM}^{3}$ and Nwafor $\mathrm{MN}^{4}$
}

${ }^{1}$ National Cardiothoracic Center of Excellence, University of Nigeria Teaching Hospital, Enugu, Nigeria

${ }^{2}$ Chairman, Global Cardiac Alliance, Memphis, USA

${ }^{3}$ National Cardiothoracic Center of Excellence, UNTH, Enugu, Nigeria

${ }^{4} \mathrm{ICU}$, National Cardiothoracic Center of Excellence, UNTH, Enugu, Nigeria

\begin{abstract}
Truncus arteriosus, also known as common arterial trunk is an unusual embryologic anomaly. It is characterized by incomplete conotuncal septation resulting in a common aortopulmonary trunk and ventricular septal defect. The first surgical repair was performed in 1962 when Behdtrendt et al. closed the VSD and used a valveless conduit to establish right ventricle-pulmonary artery continuity. Complete repair of this anomaly with a valved conduit was first reported in 1967 by McGoon et al. and remains the procedure of choice for these patients. National Cardiothoracic Center of Excellence was established in 1984. Since then it had carried out significant surgical management of simple CHD. Recently, with the aid of foreign medical missions, it was able to carry out a successful repair of truncus arteriosus type 1 , the first of its kind in Nigeria.
\end{abstract}

Keywords: Truncus arteriosus; Aortopulmonary trunk; Congenital heart disease; Hyperreflexia; Hydronephrosis

\begin{abstract}
Abbreviations: NTH: University of Nigeria Teaching Hospital; ICU: Intensive Care Unit; d-TGA: delta-Transposition of the Great Arteries; VSD: Ventricular Septal Defect; $\mathrm{SPO}_{2}$ : Percentage of Oxygen Saturation; OFC: Occipitofrontal Circumference; LICS: Left Intercostals Space; P2: Second Heart Sound; CCF: Congestive Cardiac Failure; RPA, LPA: Right Pulmonary Artery, Left Pulmonary Artery; FBC: Full Blood Count; ESR: Erythrocyte Sedimentation Rate; LFT: Liver Function Test; HB-SAg: Hepatits B Surface Antigen; HCV, HIV: Hepatitis C Virus, Human Immune Deficiency Virus; SEUC: Serum Electrolyte, Urea and creatinine; MCS: Microscopy Culture and Senstivity; PT/INR: Prothrombine Time/International Normalized Ratio; CxR: Chest x-Ray; ECG: Electrocardiogram; ASO: Anti Streptoccocal O; FFP: Fresh Frozen Plasma; GA, ETT: General Anaesthesia, Endotracheal Intubation; LVSVC: Left Superior Vena Cava; ACC: Aortic Cross Clamp; TVR: Tricuspid Valve Regurgitation; MR: Mitral Valve Regurgitation; PS: Pulmonary Senosis; PAP: Pulmonary Artery Pressure; DPO: Day Postoperative.
\end{abstract}

\section{Introduction}

Nigeria, a coastal West African country, has a population of about 170 million people It has no fully established functional cardiac center for surgical management of adult and congenital heart diseases [1]. Currently, such cases are managed on adhoc basis (medical missions from foundations based in USA, UK and India). Such centers providing such medical missions in Nigeria include University of Nigeria Teaching Hospital, UNTH, Enugu; Lagos University Teaching Hospital, LUTH; Lagos State University Teaching Hospital, LASUTH and Gwagwalada University Teaching Hospital, Abuja. Recently, in one of such missions at UNTH, Enugu, a complex and rare congenital heart disease, truncus arteriosus, type 1 was found and successfully managed, hence this report.

Truncus arteriosus is an uncommon congenital heart disease, accounting for less than $3 \%$ of all congenital heart diseases [2-4]. The features of truncus arteriosus are a single great artery arising from the base of the heart that supplies systemic, coronary and pulmonary blood flow, and ventricular septal defect. So many classifications exist for this rare defect but the most and clinical useful ones are those by Collet and
Edward in 1949 and Van Praagh in 1965 [5]. The natural history is 80\% mortality in the first year of life especially during infancy [6].

The result of physiological repair has remarkably improved over the years but pulmonary hypertension in the immediate postoperative period continues to pose a challenge. Historically, truncus arteriosus repair was first performed by McGoon et al. [7], with the use of aortic homograft including the aortic valve, with the aim of establishing continuity between right ventricle and pulmonary artery. From then till now, various methods have been developed with confusion over which method is best suited vis-à-vis the age at presentation. The frequently observed complications include conduit stenosis, truncal valve regurgitation or incompetence and or stenosis. High mortality and morbidity attend reoperation to address the listed complications.

This case report is aimed at stating unequivocally that truncus arteriosus among other complex congenital heart diseases are present in Nigeria and that a cardiac center, at University of Nigeria Teaching Hospital, Enugu has well equipped intensive care unit and personnel to manage the intricate postoperative challenges associated with its repair. However, trained local paediatric surgeon(s) are lacking, hence the foreign medical missions.

\section{Case Report}

OD is a 15 month male who lives with the parents at No 13B Jaja street, Aba, Abia state. Nigeria. They are Christians of the Redeemed Christian Mission. He presented at our service, within 4 months illness, at the age of 11 months with complaints of fast breathing that was noticed at 10 months of age, poor weight gain noticed at 9 months and 2 weeks, stiffness of the body noticed at 8 months, bluish discoloration

*Corresponding author: Nwafor IA, National Cardiothoracic Center of Excellence UNTH, Enugu, Nigeria, Tel: +2348037784860; E-mail: igbochinanya2@yahoo.com

Received April 13, 2016; Accepted April 22, 2016; Published April 29, 2016

Citation: Nwafor IA, Novick W, Adiele DK, Eze JC, Ezemba N, et al. (2016) Repair of Truncus Arteriosus, Type 1 in Nigeria: A Case Report. J Vasc Med Surg 4: 264 doi:10.4172/2329-6925.1000264

Copyright: @ 2016 Nwafor IA, et al. This is an open-access article distributed unde the terms of the Creative Commons Attribution License, which permits unrestricted use, distribution, and reproduction in any medium, provided the original author and source are credited. 
of the lips, inability to pass urine and fever noticed, all prior to presentation 4 months ago. For the above complaints, he was initially managed at another hospital. There, clinical and echocardiographic diagnosis of d-TGA, large sub-aortic VSD including moderate aortic regurgitation was made. He was subsequently referred to our center for expert management.

At our center further evaluation showed that he was acutely ill looking male in respiratory distress ( $\mathrm{RR}=60$ breaths $/ \mathrm{min})$, tachycardia (pulse rate $=160$ beats $/ \mathrm{min}$ ), deep cyanosis $\left(\mathrm{SPO}_{2}=48 \%\right.$ on room air), febrile (temp $=38^{\circ} \mathrm{C}$ ), dry mucosa, nil peripheral oedema and no lymphadenopathy. His weight was $6 \mathrm{~kg}$ ( $60 \%$ of expected weight), length $=56 \mathrm{~cm}$ (low for age) and $\mathrm{OFC}=41 \mathrm{~cm}$ (88.2\% of expected). He had precordial bulge with displaced apex beat to $5^{\text {th }}$ LICS, lateral to mild clavicular line. Heart sounds 1 and 11 with grade $3 / 6$ pansysytolic murmur maximal at the lower left sterna border with loud P2.

Liver was enlarged $8 \mathrm{~cm}$ below the right costal margin, soft and tender. Both kidneys were ballotable. Lung fields were clear. He was conscious but irritable, normal fontanel, in episthotonic posture with global hypertonia and hyperreflexia. The working diagnoses of CCF from cyanotic $\mathrm{CHD}$, cerebral palsy from perinatal asphyxia, bilateral hydronephrosis, with moderate hydration were made.

He was admitted into the ward and catheterized. Abdominal ultrasound done later excluded Hydronephrosis and urine output improved on hydration and he was subsequently managed in collaboration with the pediatric neurologists, dieticians, physiotherapists and health visiting unit. He was discharged after 7 days to continue multidisciplinary follow up.

He was subsequently followed up awaiting surgical management. However, during one of the surgical cardiac missions at our center led by Dr Williams Novick cardiac Alliance, patient was re-evaluated for surgical management. During then, a repeat echocardiography was done and the following findings were noted: single outflow tract becoming aorta and pulmonary arteries, large VSD, moderate truncal valve regurgitation; $\mathrm{RPA}=8.0 \mathrm{~mm}, \mathrm{LPA}=7.0 \mathrm{~mm}$ and coronary sinus was dilated. The diagnosis was then changed from d-TGA to truncus arteriosus type 1 .

He was worked up for surgery with the results of the following investigations satisfactorily obtained. They included FBC, ESR, LFT, HB-sAg, HCV, HIV 1 and 11, SEUC, Urinalysis, with urine MCS, PT/ INR and C $x$ R. Others were 12 lead ECG, ASO titre. Thereafter, 3 units of packed cells were cross-matched for him. Also platelets concentrates and FFP were provided. Informed consent of his parents was obtained.

Patient had open heart surgery for intra-cardiac repair. Patient was positioned supine, with GA with ETT and muscle relaxation with full cardiopulmonary monitoring. Cleansing and draping for standard median sternotomy was done. Patient had sternotomy. Intraoperative findings were: persistent LSVC, right sided aortic arch, type 1 truncus arteriosus. Aortic and bicaval cannulation was done. Aortic crossclamp applied and a bolus cardioplegia $(30 \mathrm{ml} / \mathrm{kg})$ delivered. Right atriotomy was done and noted were a $10 \mathrm{~mm}$ sub-truncal (outlet) VSD, trileaflet competent truncal valve, right and left coronary arteries (Figure 1).

Autologous pericardium was used to form the neo-MPA conduit to size 13 Hager's dilator with a monocusp valve. The truncal valve was assigned to the aorta while the branch pulmonary arteries were assigned to the neo-MPA. VSD was closed with a Gore-tex patch (Figure 2). Patient was gradually rewarmed, right atriotomy closed, de-airing done and aortic cross clamp removed. ACC time was 65 minutes and total cardiopulmonary bypass time was 253 minutes. $\mathrm{He}$ had a challenging but smoothly progressive postoperative care and recovery. Echocardiography obtained on the $14^{\text {th }}$ postoperative day revealed a VSD patch intact with no residual flow through the VSD. RPA and LPA to neo-MPA anastomoses were intact with mild PS gradient (gradient $=30 \mathrm{mmHg}$ ); Mild TVR (gradient $=35 \mathrm{mmHg}$ ); PAP $(\mathrm{TR}+\mathrm{RAP})=45 \mathrm{mmHg}$. No $\mathrm{MR}$, no vegetations, good biventricular function. No pericardial or pleural effusion. He was weaned off ventilator and extubated successfully on the $14^{\text {th }}$ post-operative day. He was placed on T-piece and continued to saturate at $95-96 \%$ on $2 \mathrm{~L} / \mathrm{min}$ intranasal oxygen and $90 \%$ on room air (Figure 3). He had prolonged hospital stay due to unstable sternum. Sternal stabilization was done on the $32^{\text {nd }}$ DPO. 11 days later he was discharged, precisely on the $43^{\text {rd }} \mathrm{DPO}$ in optimal condition. With $\mathrm{RR}=28-36$ breaths $/ \mathrm{min}$, saturation $=100 \%$ on room air, pulse rate $=108$ beats $/ \mathrm{min}$, regular and moderate volume and $\mathrm{BP}=114 / 60 \mathrm{mmHg}$. Current drugs at the time of discharge were oral frusemide, spironolactone, enalapril, cefixime and loratidine. He has been followed up at out-patient clinic on 2-weekly basis for more the 6 months with uneventful condition (Figure 4).

\section{Discussion}

Truncus arteriosus is an uncommon lesion. It accounts for 0.4$3.9 \%$ of autopsy proven cases of congenital heart defects [8]. As has been previously described, the lesion is characterized by single large arterial trunk originating from the base of the heart directly superior to a high VSD. PA originates from the trunk [9]. The defect is now correctable by closing the VSD and inserting a conduit between the right ventricle and pulmonary artery [10]. In the index patient, the conduit was a tabularized pericardium with a monocusp valve. The truncal valve which was competent was assigned to the aorta.

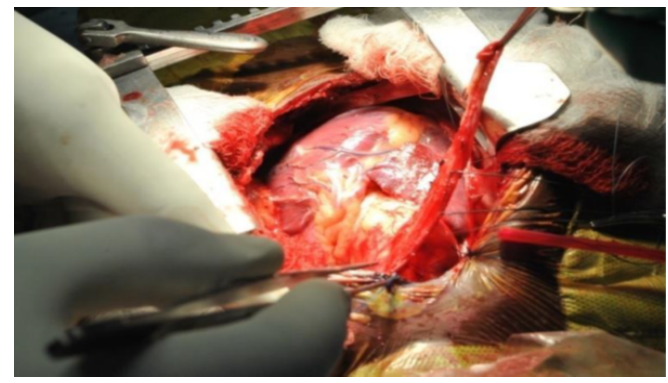

Figure 1: Sternotomy done with native pericardium being harvested.

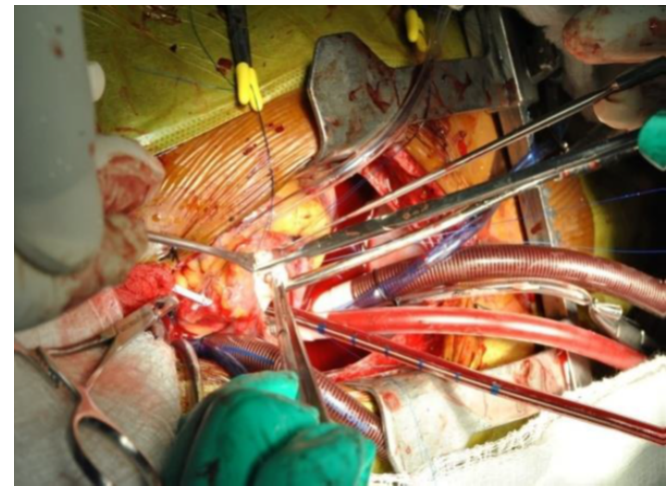

Figure 2: Patient under full cardiopulmonary bypass with VSD being repaired. 


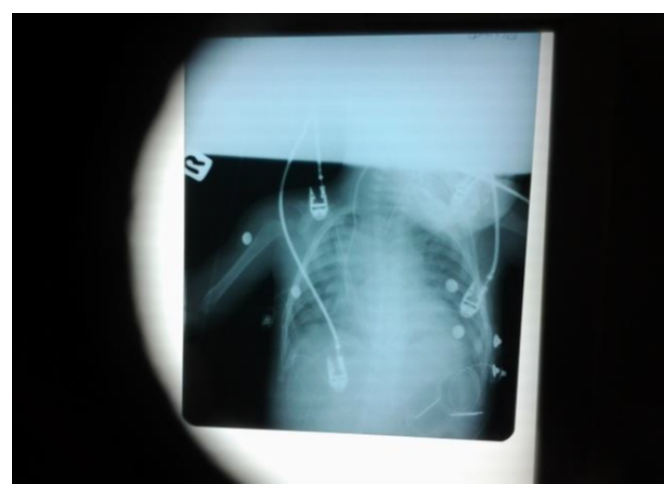

Figure 3: $1^{\text {st }}$ postoperative $\mathrm{C} \times \mathrm{R}(\mathrm{AP}$ view) in the ICU.

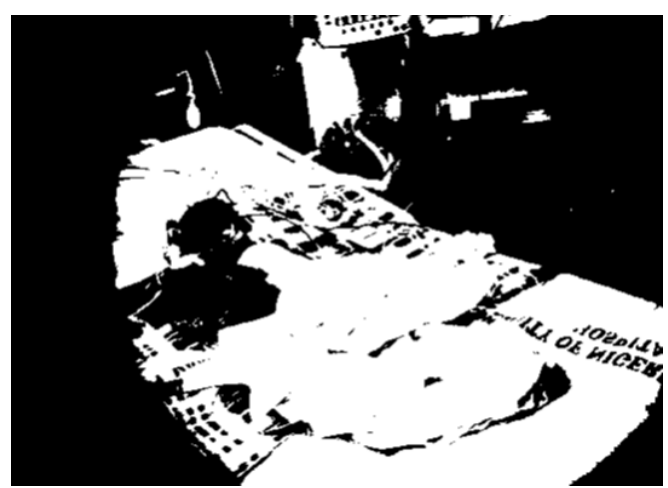

Figure 4: Patient being nursed in the ICU.

Historically, experimental work in animal model had been successful and was consequently translated into clinical application. The outcome had been successful [11]. Truncus arteriosus invariably requires operative repair. Symptoms develop in the early neonatal period indicating that early repair is required at that point [12].

As there are 3 types of truncus arteriosus, the operation and postoperative events are so challenging that the decision to operate must be weighed carefully.

Presence of other congenital defects, anatomic variations of pulmonary arteries or previous operations unrelated to the disease has been discovered not to have significant outcome in the operative and postoperative events. However, presence of truncal valve regurgitation in $25 \%$ of patients constitutes an increased difficulty during operation [13]. The truncal valve of the index patient was competent. In developed countries, aortic homograft has provided a haemodynamically satisfactory conduit between the right ventricle and the pulmonary artery [14]. Aortic calcification appears to the only drawback. In the index patient, aortic homograft was not used but tubularised native pericardium was used. In the work done by Barbero-Marcial et al. [15], pulmonary cryo-preserved heterograft, woven Dacron graft containing a glutaradehyde preserved porcine valve from Medtronic, non valved PTFE and a bovine jugular venous valve conduit have been used at various stages with or without Lecompte maneuver [16].

In our index patient, postoperative recovery was challenging, probably due to low cardiac output syndrome since patient never had prio pulmonary artery banding and or postcardiotomy syndrome. Early repair has a better outcome because delaying the repair beyond
100 days carries the risk of postoperative pulmonary hypertensive crisis and cardiac failure $[17,18]$. Our patient was 15 months of age.

Our patient is still being followed up and as at the time of this report, no known late postoperative complications like recurrent supraventricular tachyarrhythmias, subacute babacterial endocarditis and right ventricular dysfunction have been observed.

\section{Conclusion}

Congenital heart diseases, both simple and complex, are present in our country. Making accurate diagnosis can be quite challenging unlike the developed world. Also important is the issue of repairing the complex types because of the dearth of requisite personnel as well as the equipment. Foreign cardiac missions that are humanitarian in nature can bridge the gap if consistent.

\section{References}

1. Bamgbose JA (2009) Falsification of population census data in a heterogeneous Nigerian state: The fourth republic example. African Journal of political science and International Relations 3: 311-319.

2. Ebert PA, Turley K, Stanger P, Hoffman JI, Heymann MA, et al. (1984) Surgical treatment of truncus arteriosus in the first 6 months of life. Ann Surg 200: 451-456.

3. Di Donato RM, Fyfe DA, Puga FJ, Danielson GK, Ritter DG, et al. (1985) Fifteen-year experience with surgical repair of truncus arteriosus. J Thorac Cardiovasc Surg 89: 414-422.

4. Marcelletti C, McGoon DC, Mair DD (1976) The natural history of truncus arteriosus. Circulation 54: 108-111.

5. Collett RW, Edwards JE (1949) Persistent truncus arteriosus; a classification according to anatomic types. Surg Clin North Am 29: 1245-1270.

6. Van Praagh R, Van Praagh S (1965) The anatomy of common aorticopulmonary trunk (truncus arteriosus communis) and its embryologic implications. A study of 57 necropsy cases. Am J Cardiol 16: 406-425.

7. Williams JM, de Leeuw M, Black MD, Freedom RM, Williams WG, et al. (1999) Factors associated with outcomes of persistent truncus arteriosus. J Am Coll Cardiol 34: 545-553.

8. McGoon DC, Rastelli GC, Ongley PA (1968) An operation for the correction of truncus arteriosus. JAMA 205: 69-73.

9. Brown JW, Ruzmetov M, Okada Y, Vijay P, Turrentine MW (2001) Truncus arteriosus repair: outcomes, risk factors, reoperation and management. Eur J Cardiothorac Surg 20: 221-227.

10. Wallace RB, Rastelli GC, Ongley PA, Titus JL, McGoon DC (1969) Complete repair of truncus arteriosus defects. J Thorac Cardiovasc Surg 57: 95-107.

11. Rogers MA, Winship WS, Coleman AJ (1971) Correction of persistent truncus arteriosus. Thorax 26: 115-118.

12. Chen JM, Glickstein JS, Davies RR, Mercando ML, Hellenbrand WE, et al (2005) The effect of repair technique on postoperative right-sided obstruction in patients with truncus arteriosus. J Thorac Cardiovasc Surg 129: 559-568.

13. De Leval MR, McGoon DC, Wallace RB, Danielson GK, Mair DD (1974) Management of truncal valvular regurgitation. Ann Surg 180: 427-432.

14. Brawley RK, Gardner TJ, Donahoo JS, Neill CA, Rowe RD, et al. (1972) Late results after right ventricular outflow tract reconstruction with aortic root homografts. J Thorac Cardiovasc Surg 64: 314-321.

15. Barbero-Marcial M, Riso A, Atik E, Jatene A (1990) A technique for correction of truncus arteriosus types I and II without extracardiac conduits. J Thorac Cardiovasc Surg 99: 364-369.

16. Lecompte Y, Neveux JY, Leca F, Zannini L, Tu TV, et al. (1982) Reconstruction of the pulmonary outflow tract without prosthetic conduit. J Thorac Cardiovasc Surg 84: 727-733.

17. Bove EL, Lupinetti FM, Pridjian AK, Beekman RH, Callow LB, et al. (1993) Results of a policy of primary repair of truncus arteriosus in the neonate. $J$ Thorac Cardiovasc Surg 105: 1057-1065.

18. Hanley FL, Heinemann MK, Jonas RA, Mayer JE Jr, Cook NR, et al. (1993) Repair of truncus arteriosus in the neonate. J Thorac Cardiovasc Surg 105 1047-1056. 